\title{
Implications of Stratospheric Ozone Depletion upon Plant Production
}

\author{
Alan H. Teramura \\ Department of Botany, University of Maryland, College Park MD 20742
}

Scientists have now accumulated sufficient evidence to show that human activity is rapidly changing the chemical composition of trace gases in the earth's atmosphere. These changes are beginning to produce global effects on the earth's ozone layer, climate, and atmospheric chemistry. Gases of primary concern are $\mathrm{CO}_{2}$, chlorofluorocarbons (CFCs), methane $\left(\mathrm{CH}_{4}\right)$ and nitrous oxide $\left(\mathrm{N}_{2} \mathrm{O}\right)$, and tropospheric ozone $\left(\mathrm{O}_{3}\right)$, which is produced as a result of other gases (WMO, 1986). Atmospheric concentrations of all these compounds are increasing at an alarmingly rapid rate. Annual rates of increase in concentrations have been measured at between $5 \%$ and $7 \%$ for CFCs, $1 \%$ for $\mathrm{CH}_{4}, 0.2 \%$ to $0.3 \%$ for $\mathrm{N}_{2} \mathrm{O}$, and $0.5 \%$ for $\mathrm{CO}_{2}$ (WMO, 1986). The concentration of other trace gases is increasing at even a more-rapid rate. With the exception of CFCs, the changes in these gases involve natural processes; however, human activities have greatly accelerated their release into the atmosphere. For example, $\mathrm{CH}_{4}$ is naturally produced by bacterial activity in water-logged soils and in the digestive tracts of herbivores, but increasing amounts are produced by rice cultivation, cattle raising, burning biomass and mining fossil fuels (WMO, 1986). Nitrous oxide is naturally produced by denitrification and nitrification processes; however, the increased use of ammonia-based fertilizers is also increasing its concentration in the atmosphere (WMO, 1986). Increases in atmospheric $\mathrm{CO}_{2}$ concentrations are well-known and are primarily associated with the burning of fossil fuels and deforestation. It is anticipated that our atmospheric levels of $\mathrm{CO}_{2}$ will double to $600 \mathrm{ppm}$ sometime with in the next 30 to 75 years (Hansen et al., 1986).

Unlike the other trace gases mentioned above, CFCs are entirely man-made for use as refrigerants, foam-blowing agents, solvents and degreasing agents, and aerosol spray propellants. Historically, use of CFCs has grown roughly twice as fast as economic growth (Gibbs, 1986; Hammitt, 1986; Nordhaus and Yohe, 1986). The United States, Canada, Norway, and Sweden banned nonessential use of CFCs as aerosol propellants in the 1970s. Future growth in CFC use will be reduced by the recently negotiated Montreal Protocol on Substances that Deplete the Ozone Layer. Over fifty nations have now signed this landmark environmental agreement, which calls for a 50\% reduction in CFC use within 10 years. Despite these restrictions, global CFC concentrations are projected to increase due to their long atmospheric lifetimes, use by countries not party to the Montreal Protocol, and allowed use by Protocol participants (Hoffman and Gibbs, 1988).

An important consequence of this rapid increase in trace gases is that they are projected to have a large impact on global climate. All of these- $\mathrm{CO}_{2}, \mathrm{CH}_{4}, \mathrm{~N}_{2} \mathrm{O}, \mathrm{CFCs}$, and tropospheric $\mathrm{O}_{3}$-are greenhouse gases; they warm the earth's surface by allowing short wavelength radiation to pass through relatively unattenuated, but absorb some of the outgoing longwave (terrestrial) radiation and reemit some of it downward, providing an additional source of hearing. It is convenient to combine the radiative effects of all these gases and refer to the effect of "an equivalent doubling of CO?," which is projected to occur in $\approx 50$ years if present emission trends continue. Since $\mathrm{CO}_{2}$ is projected to provide only about half of the total increased greenhouse effect, the actual concentration of $\mathrm{CO}_{2}$ will double sometime after that, depending on future policy decisions. Various estimates project this to occur within the next 100 years (Mintzer, 1987).

In addition to their contribution to global warming, $\mathrm{CFCs}$ and $\mathrm{N}_{2} \mathrm{O}$ may deplete the earth's protective stratospheric ozone layer. CFCs and $\mathrm{N}_{2} \mathrm{O}$ are stable compounds with atmospheric lifetimes of up to 150 years (WMO, 1986). Their long lifetimes allow them to be photodissociated and release $\mathrm{NOCl}$, which catalytically destroys ozone.

Following an 18-month review involving over 100 of the world's leading atmospheric scientists, the International Ozone Trends Panel released its conclusive findings in Mar. 1988 that significant global ozone depletion has already occurred. The panel cited a depletion of between $1.7 \%$ and $3.0 \%$ from 1969 to 1986 at latitudes between 30 and $64^{\circ} \mathrm{N}$ (where measurements are most extensive). The panel found that this decrease is conclusively linked to atmospheric chlorine, and is in addition to the natural variation in ozone levels (NASA, 1988). In addition, the Ozone Trends Panel reconfirmed that seasonal concentrations of ozone in Antarctica have fallen by $50 \%$ over the past decade, and that the weight of evidence indicates that manmade chlorine species are responsible for the depletion (NASA, 1988).

At this time, it is impossible to project the future ozone losses that will be associated with further inevitable increases in stratospheric chlorine and bromine. Tolbert et al. (1987), for example, have shown that heterogeneous reactions can occur on sulfate aerosols, raising the possibility of nonlinear depletion over parts of the globe. Blake and Rowland (1988) have suggested that $\mathrm{CH}_{4}$ can transport water vapor to the stratosphere and provide reaction sites for heterogeneous chemistry. Consequently, it would be premature to consider the threat of depletion to be gone, although the Montreal Protocol and announcements about its revision provide a prognosis for ozone layer protection that appears good.

Depletion of the ozone layer is of concern because stratospheric ozone is the primary attenuator of solar ultraviolet-B radiation (UV$B$ region, between 290 and $320 \mathrm{~nm}$ ). A decrease in this ozone layer would lead to increases in W-B reaching the earth's surface. Though representing only a small fraction of the total solar electromagnetic spectrum, UV-B has a disproportionately large photobiological effect.

The reason for concern over stratospheric ozone depletion and the ensuing increase in solar UV radiation is that many important biological macromolecules, including proteins, DNA, and phytohormones, all have appreciable absorption coefficients in the UV region (Giese, 1964). This results in a whole array of physiological and biochemical effects, including direct effects on the primary reactions of photosystem II, dark respiration, stomatal conductance, and the protein, lipid, and carbohydrate composition of plant tissues. etc. (Table 1) (Teramura, 1983; Tevini and Teramura, 1989). These physiological changes produce altered tissues and structures in plants. Among the most characteristic of these alterations are reductions in leaf area and plant stunting resulting from a shortening of internode length. A change in the pattern of biomass allocation can result in proportionately more biomass going into vegetative structures and concomitantly less into reproductive ones, thereby reducing harvestable yield. Under intense solar UV, bronzing, chlorosis. and other direct effects can be observed on sensitive plant tissues, resulting in reduced physiological performance and possibly affecting the qualify of fruits and vegetables.

Although economically important crops represent only $10 \%$ of global net primary productivity, because of their importance to human nutrition, it is not surprising that $>90 \%$ of our understanding of UV effects on plants comes from studies on these crops (Table 2 ). To date, the scientific community has screened $>300$ species and cultivars of plants, and, alarmingly, over one-half of these showed sensitivity to UV radiation (Teramura, 1986; Tevini and Teramura, 1989). The most sensitive plant families include members of the Fabaceae (beans and peas), Cucurbitaceae (squash and 
Table 1. A summary of the effects of UV-B radiation on plant physiology and growth [adapted from Tcramura (1983), see for specific references and details of effects].

\begin{tabular}{|c|c|}
\hline A. Physiological/biochemical effects & Relative changes \\
\hline Direct effects on photosynthesis & - \\
\hline Hill rcaction & - \\
\hline Elcctron transport & - \\
\hline RuBP carboxylase & - \\
\hline PEP carboxylase & - \\
\hline Dark respiration & $+1-$ \\
\hline Stomatal conductance & $+1-$ \\
\hline Photosynthetic pigments & - \\
\hline Nonphotosynthetic pigments & + \\
\hline Soluble protcins & $+1-$ \\
\hline Lipid composition & $\Delta$ \\
\hline Solubic carbohydrates & $+1-$ \\
\hline Plant hormones & - \\
\hline Ion transport & - \\
\hline Cuticular wax composition & $\Delta$ \\
\hline \multicolumn{2}{|l|}{ B. Morphological/anatomical cffects } \\
\hline Leaf arca & - \\
\hline Spccific leaf wi & + \\
\hline Bronzing/glazing/chlorosis & + \\
\hline Secdling growth & - \\
\hline Dry matter production/allocation & $\Delta$ \\
\hline Yicld & - \\
\hline
\end{tabular}

${ }^{\mathrm{z}}$ Increase $=+$; decrease $=-$; change in composition or pattern of allocation $=\mathrm{A}$.

Table 2. Survey of UV studies by major terrestrial plant ecosystem [after Whittakcr, (1975)].

\begin{tabular}{lcc}
\hline \hline Ecosystcm & $\begin{array}{c}\text { Global NPP } \\
(C)\end{array}$ & $\begin{array}{c}\text { Included in } \\
\text { UV study }\end{array}$ \\
\hline Tropical forest & 42 & No \\
Tcmpcrate forest & 13 & Yes \\
Savanna & 12 & No \\
Boreal forest & 8 & No \\
Agricultural & 8 & Yes \\
Woodland and & & \\
$\quad$ scrubland & 5 & No \\
Temperate & & \\
$\quad$ grassland & 5 & Yes \\
Swamp and marsh & 4 & No \\
Descri and scmidesert & 2 & No \\
Tundra and alpinc & 1 & Yes \\
\hline
\end{tabular}

melons), and Brassicaceae (mustard and cabbage).

Only 10 field studies have examined the effects of UV on crop yield in 22 species of plants (Table 3) and yield was reduced in more than half of the crops studied. The range of response shown for each crop species was partially due to differences in experimental treatments and partially due to intraspecific (cultivar) differences in UV sensitivity. A detailed study was conducted at the Univ. of Maryland on soybean, where several soybean varieties were intensively examined for a 6-year period from 1981 to 1986 (Teramura and Sullivan, 1988). Increased levels of UV were artificially supplied from filtered fluorescent sunlamps suspended above plants growing in the field. In a particularly sensitive cultivar, Essex soybean yield was reduced by $19 \%$ to $25 \%$ in 4 of the 6 years by UV-B radiation levels that simulated a $25 \%$ ozone depletion (Table 4). In years with apparently little UV effectiveness (1983 to 1984), all plants experienced a considerable amount of drought stress. Parallel field and greenhouse studies have demonstrated that under water stress, the effects of UV-B radiation are masked (Murali and Teramura, 1986; Sullivan and Teramura, 1989). A similar masking effect was found in studies of UV-B-irradiated, mineral-deficient plants (Murali and Teramura, 1985). These emphasize the importance of understanding the interactions of UV-B with other plant stress factors. Additionally, it suggests that the impacts of UV-B radiation might be greatest under conditions optimal for growth, i.e., irrigated and fertilized regions. Yield quality can also be adversely affected as seen in the protein and oil content of UV-B- irradiated soybean seed (Table 4). Other investigators have also reported possible UV-induced reductions in quality for potato, tomato, and sugar beet (Teramura, 1986). In addition to these direct effects of UV radiation, yield may be further reduced by indirect effects resulting from increased losses due to weeds (Gold and Caldwell, 1983; Barnes et al., 1988), diseases (Carns et al., 1978; Biggs et al., 1984) and insects. When combined with the direct effects of UV-B radiation these may result in greater overall losses.

Although forest tree species represent up to $80 \%$ of global net primary productivity, very little is known of the effects of UV radiation on these species (Table 2). In fact, only 15 temperate forest species have been examined for $\mathrm{W}$ sensitivity and nearly half of these were shown to be sensitive. Loblolly pine, red pine, and lodgepole pine were particularly sensitive (Sullivan and Teramura, 1988, 1989). Due to the long lifespan of trees and the lengthy time required for breeding, forests may be particularly vulnerable to increases in UV-B radiation resulting from stratospheric ozone depletion.

Very little is known of the effects of UV on natural, noncultivated ecosystems. To date, only 30 to 40 species of native plants have been screened for UV-B radiation sensitivity. When examining natural plant communities, it appears that plants from naturally high UV environments are more resistant to UV than those from low UV environments (Caldwell et al., 1982). For example, in one study of some native Hawaiian plants collected along an elevational gradient on Mount Haleakala on the island of Maui, it appeared that plants collected near sea level were much more sensitive to UV radiation than those collected from high on the mountain. This increase in UV tolerance with elevation coincides quite well with the increase in UV radiation along the elevational gradient. Due to this differential sensitivity, the biodiversity of natural ecosystems may be significantly altered.

In light of the differences in UV sensitivity found among crop and native plants, it is clear that plants have evolved various protective and repair mechanisms to UV radiation (Beggs et al., 1986). These include specific enzyme-mediated repair mechanisms such as photoreactivation to generalized repair processes mediated through overall growth reduction. One very effective means of protection results from the direct UV-B stimulation of plant pigment production in the upper epidermal cell layers of leaves, the layers that absorb UV radiation, preventing it from penetrating deeper into underlying tissues and causing damage. These pigments include flavonoids, which are colorless, thereby allowing visible radiation to pass into the leaves to drive photosynthesis, but highly absorptive to damaging $\mathrm{W}$ radiation. It has been clearly demonstrated that $W$ radiation specifically activates the genes that control the expression of several key enzymes along the phenylpropenoid pathway leading to flavonoid biosynthesis (Hahlbrock and Grisebach, 1979). The degree of flavonoid production has been closely linked with UV sensitivity on several species of plants, including soybean and cucumber (Murali and Teramura, 1986).

\section{CONCLUSIONS}

There are 10 major terrestrial plant ecosystems in the world that include > 300 plant families. The effects of enhanced levels of UV$\mathrm{B}$ radiation resulting from stratospheric ozone depletion have been studied in $<10 \%$ of these families and in only four of these ecosystems. Most of our knowledge of UV-B radiation effects is derived from agricultural crops and little information exists for longlived perennials such as trees or for noncultivated, natural plant communities.

Plant response to increased levels of UV-B radiation varies markedly both interspecifically and intraspecifically. Presently, the physiological and genetic bases for these inherent differences are not well-understood. However, UV-tolerant plants do possess various types of UV-protective and repair processes, which suggests that increased UV resistance in crops might be achieved via breeding programs. Unfortunately, we currently lack information on the genetic basis and heritability of UV resistance to estimate the feasibility of such crop improvement programs. Furthermore, selective breeding may not be possible in long-lived perennials such as trees 
Table 3. Summary of field studies examining the effects of UV-B radiation on crop yields. Values represent percent changes from controls [adapted from Teramura (1986)].

\begin{tabular}{|c|c|c|c|c|c|c|c|c|c|c|}
\hline Crop species & $\begin{array}{l}\text { Ambler } \\
\text { ct al. } \\
(1978) \\
(1)^{2}\end{array}$ & $\begin{array}{c}\text { Barnes } \\
\text { ct al. } \\
(1988) \\
(2)^{2}\end{array}$ & $\begin{array}{c}\text { Bartholic } \\
\text { et al. } \\
(1975) \\
(2)\end{array}$ & $\begin{array}{c}\text { Becwar } \\
\text { et al. } \\
(1982) \\
(2)\end{array}$ & $\begin{array}{l}\text { Biggs and } \\
\text { Kossuth } \\
(1978) \\
(2)\end{array}$ & $\begin{array}{l}\text { Biggs } \\
\text { ct al. } \\
(1984) \\
(2)\end{array}$ & $\begin{array}{c}\text { Eisensiark } \\
\text { cl al. } \\
(1984) \\
(2)\end{array}$ & $\begin{array}{c}\text { Esscr } \\
(1980) \\
(1)\end{array}$ & $\begin{array}{c}\text { Hart } \\
\text { et al. } \\
(1975) \\
(1)\end{array}$ & $\begin{array}{l}\text { Teramura } \\
\text { and } \\
\text { Sullivan } \\
(1988) \\
(2)\end{array}$ \\
\hline $\begin{array}{l}\text { Cucurbita maxima } \\
\text { Cucurbita pepo }\end{array}$ & 0 & & & & $-1410-90$ & & & & & \\
\hline Phaseolus vulgaris & & 0 & $+1210+15$ & & & -5 & & $+5310-75$ & & \\
\hline Capsicum annum & & & & & & & & & $-(?)$ & \\
\hline $\begin{array}{l}\text { Glycine max } \\
\text { Cynodon dacrulon }\end{array}$ & 0 & & & & & 0 & & & 0 & $+2210-25$ \\
\hline Beta vulgaris & 0 & & & & & & & & & \\
\hline $\begin{array}{l}\text { Brassica oleraceae } \\
\text { var. capitata }\end{array}$ & & & & & & & & $+1910-49$ & & \\
\hline Nicotiana tobaccum & & & & & & & & & 0 & \\
\hline Raphanus sativus & & & & 0 & & & & & & \\
\hline Pennisesum glaucum & & & & & & & & & 0 & \\
\hline Solanum tuberosum & & & & 0 & 0 & & & -2 to -41 & & \\
\hline $\begin{array}{l}\text { Brassica juncea } \\
\text { Vigna unguiculata }\end{array}$ & & & & & $\begin{array}{l}-910-43 \\
-1810-38\end{array}$ & & & & & \\
\hline Oryza sativa & & & & & & 0 & & & & \\
\hline Arachis hypogaea & & & & & 0 & & & & 0 & \\
\hline
\end{tabular}

${ }^{\mathrm{z}}(1)$ Unfiltered sunlamps; (2) filtered sunlamps.

Table 4. Summary of UV effects on soybean yield and quality. ${ }^{\mathrm{z}}$

\begin{tabular}{lccr}
\hline \hline & & \multicolumn{2}{c}{$\begin{array}{c}\text { Change in seed quality } \\
(\%)\end{array}$} \\
\cline { 3 - 4 } Ycar & Change in yield $(\%)$ & Protein & Oils \\
\hline 1981 & -25 & & \\
1982 & -23 & -5 & -2 \\
1983 & +6 & -4 & +1 \\
1984 & -7 & 0 & -2 \\
1985 & -20 & 0 & 0 \\
1986 & -19 & 0 & -1 \\
\hline
\end{tabular}

${ }^{7}$ From A.H.T. (unpublished) and Teramura and Sullivan (1988)

nor applicable to noncultivated, natural plant communities. UV-B radiation may shift the competitive balance among species, resulting in an alteration of plant biodiversity. Therefore, natural plant communities and forests may be particularly vulnerable to increases in UV radiation resulting from ozone depletion.

In addition to an increase in UV-B radiation, other climatic factors also are anticipated to change concomitantly in the future. These include increases in atmospheric $\mathrm{CO}_{2}$ concentrations, global warming, changes in the pattern of precipitation, increases in tropospheric (ground level) pollutants such as oxides of $\mathrm{N}, \mathrm{S}$, and $\mathrm{O}_{3}$, etc. Presently, only scant information exists on the effects of UV-B radiation in combination with these other changes. It is clear, however, that interactions with these other factors may greatly modify UV effectiveness. Therefore, it is currently difficult to assess the question of the overall potential impacts of increasing UV-B radiation resulting from stratospheric ozone depletion on global crop production. Much more information is still required to describe and evaluate these effects on plants. Particularly important would be field validation studies using economically important crops and forest species, as well as field -tests on natural ecosystems. Also, by understanding the adaptive mechanisms that UV-resistant plants already possess, we may be able to mitigate some of the deleterious impacts of UV-B radiation on agriculturally important crops.

\section{Literature Cited}

Ambler, J.E., R.A. Rowland, and N.K. Maher. 1976. Response of selected vegetable and agronomic crops to increased UV-B irradiation under field conditions. UV-B Biological and Climatic Effects Research (BACER), Final Rpr. EPA-IAG-D6-0168, EPA, Washington, D.C.

Barnes, P.W., P.W. Jordan, W.G. Gold, S.D. Flint, and M.M. Caldwell. 1988. Competition, morphology and canopy structure in wheat (Triticum aestivum L.) and wild oat (Avena fatua L.) exposed to enhanced ultraviolet-B radiation. Funct. Ecol. 2:319-320.

Bartholic, J.F., L.H. Halsey, and L.A. Garrard. 1975. Field trials with fillers to test for effects of UV radiation on agricultural productivity, $\mathrm{p}$. 61-71. In: D.S. Nachtwey, M.M. Caldwell, and R.H. Biggs (eds.). Climatic Impact Assessment Program (CIAP), Monogr. 5. U.S. Dept. Transportation, Rept. no. DOT-TST-75-55, Natl. Technol. Info. Serv., Springfield, Va.

Bccwar, M.R., F.D. Moore III, and M.J. Burke. 1982. Effects of deletion and enhancement of ultraviolct-B $(280-315 \mathrm{~nm})$ radiation on plants grown at $3000 \mathrm{~m}$ elevation. J. Amer. Soc. Hort. Sci. 107:771-779.

Beggs, C.J., U. Schnewidcr-Zicbert. and E. Wellmann. 1986. UV-B radiation and adaptive mechanisms in plants, p. 235-250. In: R.C. Worrest and M.M. Caldwell (eds.). Stratospheric ozone rcduction, solar ultraviolet radiation and plant life. Springcr-Verlag, Berlin.

Biggs, R.H. and S.V. Kossuth. 1978. Effects of ultraviolet-B radiation enhancement under field conditions on potatoes, tomatoes, corn. rice, southern peas, peanuts, squash. mustard and radish. UV-B Biological and Climatic Effects Research (BACER), Final Rpr. EPA, Washington, D.C.

Biggs, R.H., P.G. Webb, L.A. Garrard, T.R. Sinclair, and S.H. West. 1984. The effects of enhanced ultraviolet-B radiation on rice, wheat, corn, soybean, citrus and duckweed. Year 3 Interim Rpt. Env. Protection Agency Rpt. 808075-03, EPA, Washington. D.C.

Blake, D.R. and F.S. Rowland. 1988. Continuing worldwidc increase in tropospheric methane, 1978 to 1987 . Science 239:1129-1131.

Caldwcll, M.M., R. Robberecht, R.S. Nowak, and W.D. Billings. 1982. Differential photosynthetic inhibition by ultraviolet radiation in species from the arctic-alpine life zone. Arctic and Alpine Res. 14:195-202.

Cams, H.R., J.H. Graham, and S.J. Ravitz. 1978. Effects of UV-B radiation on selected leaf pathogenic fungi and on disease severity. EPA-IAGD6-0168. BACER Program, EPA, Washingron, D.C.

Eisensfark, A., G.H. Perrot, G. Ulmer, and C.D. Miles. 1985. Enhanced UV-B irradiation (290-320 nm) on corn (Zea mays L.) I. Effects on 
growth and yield. Env. Protection Agency Final Rpt., EPA, Washington. D.C.

Esser, G. 1980. Einfluss eincr nach schadstoffimission vermehrten einstrahlung von UV-B-licht auf kulturpflanzen, 2. Vcrsuchsjahr. Bericht Battelle Institut E.V. Frankfurt. BF-R-63, 984-1.

Gibbs, M.J. 1986. Scenarios of CFC use: 1985-2075. In: J.S. Hoffman (ed.). Assessing the risks of trace gases that can modify the stratosphere. vol. VI; Technical Support Documentation. Production Projecttons, EPA 400/1-87-001F, EPA, Washington, D.C.

Giese, A.C. 1964. Studies on ultraviolet radiation action upon animal cells. p. 303-245. In: A.C. Giese (ed.). Photophysiology. vol. 2, Academic, New York.

Gold, W.G. and M.M. Caldwcll. 1983. The effects of ultraviolet-B radiation on plant competition in terrestrial ecosystems. Physiol. Plant 58:435444.

Hart. R.H., G.E. Carlson, H.H. Klueter, and H.R. Carns. 1975. Response of economically valuable species to ultraviolet radiation, p. 263-275. In: D.S. Nachtway, M.M. Caldwell, and R.H. Biggs (eds.). Climatic Impacts Assessment Program (CIAP), Monogr. 5. U.S. Dept. Transportation, Rpt. no. DOT-TST-75-55, Natl. Technol. Info. Serv.. Springfield. Va.

Hahlbrock, K. and H. Grisebach. 1979. Enzymic controls in the biosynthesis of lignin and flavonoids. Ann. Rev. Plant Physiol. 30:108-130.

Hammitt. J.K. 1986. Product uses and market trends for potential ozone depleting substances, 1985-2000. In: J.S. Hoffman (ed.). Assessing the risks of trace gases that can modify the stratosphere. vol. VI; Technical Support Documentation. Production Projecttons. EPA 400/1-87-001F, EPA. Washington, D.C.

Hansen, J., A. Lacis, D. Rind, G. Russel, I. Fung, P. Ashcraft, S. Lebedeff. R. Ruedy, and P. Stone. 1986. The greenhouse effect: Projections of global climate change, p. 199-218. In: J.G. Titus (ed.). Effects of changes in stratospheric ozone and global climate. vol. VI; U.S. Env. Protection Agency, Washington, D.C.

Hoffman. J.S. and M.J. Gibbs. 1988. Future concentrations of stratospheric chlorine and bromine. EPA/400/1-88/005. U.S. Env. Protection Agency, Washington, D.C.

Wintzer, I. 1987. A matter of dcgrees: The potential for controlling the greenhouse effect. Research Rpt. no. 5. World Resources Inst., Washington, D.C.

Murali, N.S. and A.H. Teramura. 1985. Effects of UV-B irradiance on soybean. VI. Influence of phosphorus nutrition on growth and flavonoid content. Physiol. Plant. 63:413-416.

Murali, N.S. and A.H. Teramura. 1986. Effectivencss of WV-B radiation on the growth and physiology of field-grown soybean modified by water stress. Photochem. Photobiol. 44:215-220.

Nordhaus, W.D. and G.W. Yohe. 1986. Probablistic projections of chlorofluorocarbon consumption. In: J.S. Hoffman (ed.). Assessing the risks of trace gases that can modify the stratosphere. vol. VI; Technical Support Documentation. Production Projections. EPA 400-1-87-001F, U.S. Env. Protection Agency. Washington, D.C.

Sullivan, J.H. and A.H. Teramura. 1988. Effects of ultraviolet-B irradiation on seedling growth in the pinaceae. Amer. J. Bot. 75:225-230.

Sullivan, J.H. and A.H. Teramura. 1989. The effects of ultraviolet-B radiation on loblolly pine: 1 . Growth, photosynthesis and pigment production in greenhouse-grown saplings. Physiol: Plant. (In press.)

Sullivan. J.H. and A.H. Teramura. 1989. The interaction between supplemental ultraviolet-B irradiation and drought on soybean growth and physiology. Plant Physiol. (In press.)

Teramura, A.H. 1983. Effects of ultraviolet-B irradiances on soybean. Plant Physiol. 65:483-488.

Tcramura, A.H. 1986. Current risks and uncertainties of stratospheric ozone depletion upon plants. Risk Assessment for Env. Protection Agency.

Teramura, A.H. and J.H. Sullivan. 1988. Effects of ultraviolet-B radiation on soybean yield and seed quality. Env. Pollut. 53:477-478.

Tevini, M. and A.H. Teramura. 1989. UV-effects on terrestrial plants. Photochem. Photobiol. 50:479-487.

Tolbert, M.A., M.J. Rossi, R. Malhotra, and D.M. Golden. 1987. Reaction of chlorine nitrate with hydrogen chloride and water at Antarctic temperatures. Science 238:1258-1260.

Whittaker, R.H. 1975. Communities and ecosystems. Macmillan, New York. WMO. 1986. Atmospheric ozone 1985. Assessment of our understanding of the processes controlling its present distribution and change. World Meteorological Organization Global Ozone Rcs. and Monitoring Proj., Rpt. no. 16, WMO, Geneva, Switzerland. 